\title{
Data report: organic matter, carbonate, and stable isotope stratigraphy from IODP Expedition 346 Sites U1426, U1427, and U1429'
}

\author{
H.D. Black, ${ }^{2}$ W.T. Anderson, ${ }^{2}$ and C.A. Alvarez Zarikian ${ }^{3}$
}

\section{Chapter contents}

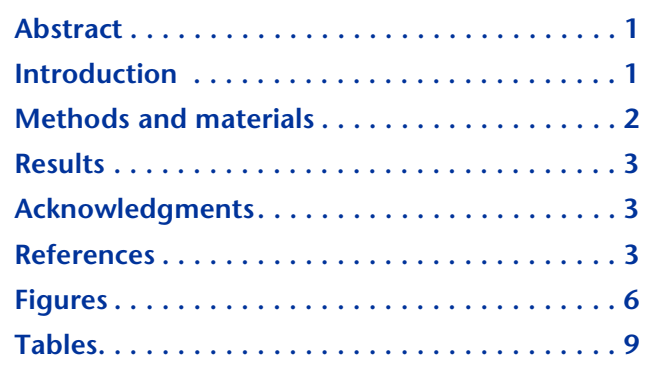

'Black, H.D., Anderson, W.T., and Alvarez Zarikian, C.A., 2018. Data report: organic matter, carbonate, and stable isotope stratigraphy from IODP Expedition 346 Sites U1426, U1427, and U1429. In Tada, R., Murray, R.W., Alvarez Zarikian, C.A., and the Expedition 346 Scientists, Proceedings of the Integrated Ocean Drilling Program, 346: College Station, TX (Integrated Ocean Drilling Program).

doi:10.2204/iodp.proc.346.204.2018

${ }^{2}$ Department of Earth and Environment, Marine Sciences Program, Florida International University, North Miami FL 33181, USA. Correspondence author: hblac012@fiu.edu

${ }^{3}$ International Ocean Discovery Program, Texas A\&M University, College Station TX 77834, USA.

\section{Abstract}

Organic matter concentrations and organic carbon and nitrogen isotopes are reported for sediments drilled during Integrated Ocean Drilling Program Expedition 346. The Japan Sea/East Sea sediments from Sites U1426 and U1427 feature a range of total organic carbon (\%TOC) between $0.16 \%$ and $6.36 \%$, total nitrogen $(\% \mathrm{~N})$ between $0.04 \%$ and $0.39 \%, \delta^{13} \mathrm{C}$ values between $-25.87 \%$ and $-19.56 \%$, $\delta^{15} \mathrm{~N}$ values between $3.33 \%$ and $13.08 \%$, and carbonate concentrations $\left(\% \mathrm{CaCO}_{3}\right)$ between $0 \%$ and $44.29 \%$. The East China Sea sediments from Site U1429 feature a range of \%TOC between $0.10 \%$ and $2.85 \%$, $\% \mathrm{~N}$ between $0.02 \%$ and $1.22 \%, \delta^{13} \mathrm{C}$ values between $-24.74 \%$ and $17.73 \%$, $\delta^{15} \mathrm{~N}$ values between $3.59 \%$ and $13.40 \%$, and $\% \mathrm{CaCO}_{3}$ between $0.70 \%$ and $42.84 \%$. Both organic matter content and stable isotopes are well correlated with $\mathrm{b}^{*}$ sediment color reflectance values and infer decreased surface productivity and suboxic to anoxic environments during glacial periods and increased productivity and deep-water ventilation during interglacial periods in the Japan Sea/East Sea.

\section{Introduction}

To better understand how climatic and oceanic changes in the Japan Sea/East Sea and East China Sea affected primary production in surface water, a high-resolution record of organic matter content is needed. Calcium carbonate $\left(\% \mathrm{CaCO}_{3}\right)$, total organic carbon (\%TOC), total nitrogen $(\% \mathrm{~N})$, carbon stable isotope $\left(\delta^{13} \mathrm{C}\right)$, and nitrogen stable isotope $\left(\delta^{15} \mathrm{~N}\right)$ contents of sediment samples are all widely used proxies for primary productivity in surface water as a result of paleoceanographic changes. These geochemical proxies are functions of nutrient availability (Mahaffey et al., 2003), primary productivity rates (Fry and Sherr, 1984), and differing organic matter source areas (O'Leary, 1981; Peterson and Howarth, 1987).

However, degradation of organic matter in both the water column and sediment surface can cause substantial alteration of organic matter from its original composition (Canuel and Martens, 1996; Lehmann et al., 2002), especially in the case of denitrification in anoxic water columns (Cline and Kaplan, 1975; Mariotti et al., 1981; Montoya et al., 1991; Altabet et al., 1999). Although the total amount of organic matter deposited in the sedimentary record is only a small portion of the original organic matter produced, it 
typically still contains accurate geochemical records (Meyers and Eadie, 1993) and therefore can be used as a proxy to determine past paleoceanographic and paleoenvironmental conditions.

Paleoproductivity proxies such as $\% \mathrm{CaCO}_{3}, \%$ TOC, $\% \mathrm{~N}, \delta^{13} \mathrm{C}$, and $\delta^{15} \mathrm{~N}$ are best used in conjunction with other proxies such as benthic foraminifer assemblages, biogenic silica concentrations, and trace element geochemistry. Therefore, these reported data should be used as a complementary guide to paleoproductivity levels using additional productivity proxies.

Here, we evaluated the $\mathrm{CaCO}_{3}, \mathrm{TOC}, \mathrm{N}, \delta^{13} \mathrm{C}$, and $\delta^{15} \mathrm{~N}$ concentrations in sediment cores retrieved from Integrated Ocean Drilling Program (IODP) Expedition 346 in the Japan Sea/East Sea and East China Sea. Expedition 346 drilling objectives were successfully completed with the retrieval of continuous sedimentary sequences at seven sampling sites in the Japan Sea/East Sea and two sampling sites in the East China Sea during the summer of 2013 (Fig. F1; see the "Expedition 346 summary" chapter [Tada et al., 2015a]).

IODP Site U1426 is in the Yamato Basin near the top of the Oki Ridge. It is located in the same location as Ocean Drilling Program Site $798 \quad\left(37^{\circ} 2.00^{\prime} \mathrm{N}\right.$, $\left.134^{\circ} 48.00^{\prime} \mathrm{E}\right)$ at 903 meters below sea level (mbsl). Four holes were drilled at this location. Hole U1426A had the best recovery of $396.7 \mathrm{~m}$, extending from the Pliocene to the Holocene. IODP Site U1427 is also in the Yamato Basin near the outer margin of the continental shelf near the coast of Honshu Island. It is located at $35^{\circ} 57.92^{\prime} \mathrm{N}, 134^{\circ} 26.06^{\prime} \mathrm{E}$ and is the shallowest site at $330.3 \mathrm{mbsl}$. Three holes were cored at Site U1427 with Hole U1427A recovering $548.6 \mathrm{~m}$ of sediment, extending from the lower Pleistocene to the Holocene. IODP Site U1429 is located in the northernmost part of the East China Sea in the Okinawa Trough at $31^{\circ} 37.04^{\prime} \mathrm{N}, 128^{\circ} 59.85^{\prime} \mathrm{E}$ and 732 mbsl. Three holes were cored at Site U1429, with Hole U1429A recovering the greatest amount (190.3 $\mathrm{m}$ ) of sediment, extending from the middle Pleistocene to the Holocene.

Sediments recovered during drilling were predominantly fine-grained biogenic siliceous and carbonate oozes with distinct light-dark sedimentary cycles. The dark layers were mostly laminated, whereas the light layers were homogeneous to bioturbated. Meter-scale alternations in the light and dark sedimentary units record orbital-scale variations in surface and deep-water circulations, whereas centimeterscale alternations in the light and dark sequences record millennial-scale climatic oscillations (see the
"Expedition 346 summary" chapter [Tada et al., 2015a]). Previous studies have demonstrated that the light-dark sedimentary cycles were synchronous basin wide and that they can be correlated between sites in the study area (Tada et al., 1992; Watanabe et al., 2007).

The lowering of glacioeustatic sea level during glacial periods limited influx of the Tsushima Warm Current (TWC) into the Japan Sea/East Sea through the Tsushima Strait. With less input from the TWC and increased contribution from precipitation, the sea became nearly isolated and a low-salinity surface layer developed (Oba et al., 1991; Tada et al., 1999; Kitamura et al., 2001; Khim et al., 2008). This low-salinity layer limited deep-water ventilation resulting from increased water column stratification (Oba et al., 1991) and caused suboxic to anoxic bottom water conditions, which are associated with organicrich, dark sedimentary layers (Watanabe et al., 2007; Khim et al., 2008). Light layers are associated with oxic conditions during interglacial and interstadial periods when there was a significant influx of the TWC through the Tsushima Strait (Tada et al., 1992, 1999).

The purpose of this research was to determine how glacioeustatic sea level changes and the resulting variation in the influx of water though the Tsushima Strait affected primary productivity rates and organic matter sources in the Japan Sea/East Sea on an orbital timescale. By comparing the Japan Sea/East Sea sites to the East China Sea sites, a better understanding of the timing and degree of isolation of the Japan Sea/East Sea during glacial lowstands can be developed.

\section{Methods and materials}

All sedimentary organic matter samples were analyzed in the Southeast Environmental Research Center's Stable Isotope Laboratory (SERC SIL) at Florida International University (USA). All samples were dried and ground until fine before being homogenized in a SPEX 8000M mixer/mill for $5 \mathrm{~min}$. Samples prepared for carbon isotope analysis were decarbonated by acidifying $\sim 0.1 \mathrm{~g}$ of ground sediment sample in a $10 \% \mathrm{HCl}$ bath for $24 \mathrm{~h}$ three times followed by decantation in deionized water to rinse away acid residue. An aliquot of $5 \mathrm{mg}$ of decarbonated sediment for \%TOC and $\delta^{13} \mathrm{C}$ analysis and 10 $\mathrm{mg}$ of nondecarbonated sediment for $\% \mathrm{~N}$ and $\delta^{15} \mathrm{~N}$ analysis were compacted in $5 \mathrm{~mm} \times 9 \mathrm{~mm}$ tin capsules and analyzed in a NA 1500 elemental analyzer coupled to a Thermo Delta $\mathrm{C}$ isotope ratio mass spectrometer. 
All isotope data are expressed as delta notation $(\delta \%)$, using the following equation:

$$
\delta R=\left[\left(R_{\text {sample }}-R_{\text {standard }}\right) / R_{\text {standard }}\right] \times 1000,
$$

where $R_{\text {sample }}$ is the ratio of the heavy to light isotope in the sample and $R_{\text {standard }}$ is the ratio of the heavy to light isotope in the standard (Coplen, 2011). The $\delta^{13} \mathrm{C}$ and $\delta^{15} \mathrm{~N}$ data are reported in permil vs. Vienna Peedee belemnite and air, respectively.

The procedure for processing inorganic carbon (\%IC) samples followed a similar method to shipboard analyses (see the "Methods" chapter [Tada et al., $2015 \mathrm{~b}]$ ). An aliquot of $15 \mathrm{mg}$ of ground, homogenized sample was acidified in $10 \mathrm{~mL}$ of $10 \% \mathrm{HClO}_{4}$ in a UIC CM140 coulometer for \%IC analysis. \%Ca$\mathrm{CO}_{3}$ was calculated from \%IC by multiplying by a factor of 8.33 under the assumption that all inorganic carbon acts as $\mathrm{CaCO}_{3}$.

All $b^{*}$ data were collected shipboard during Expedition 346 using an Ocean Optics USB4000 spectrometer at $5 \mathrm{~mm}$ resolution (see the "Methods" chapter [Tada et al., 2015b]).

\section{Results}

$\% \mathrm{CaCO}_{3}, \% \mathrm{TOC}, \% \mathrm{~N}, \delta^{13} \mathrm{C}$, and $\delta^{15} \mathrm{~N}$ concentrations in sediment samples are plotted for Sites U1426, U1427, and U1429 in Figures F2, F3, and F4, respectively. These data are also recorded in Tables T1, T2, and T3. Tada et al. (1999) indicated that sedimentary units that were typically deeper blue and had relatively less carbonate were deposited during glacial periods. Sites U1426 and U1427 show decreased $\% \mathrm{CaCO}_{3}, \% \mathrm{TOC}$, and $\% \mathrm{~N}$ and relatively depleted $\delta^{13} \mathrm{C}$ and $\delta^{15} \mathrm{~N}$ values (approximately $-26 \%$ to $-24 \%$ o and $\sim 2 \% 0-7 \%$, respectively) when compared with other sediments deposited during the interglacials (e.g., periods with higher carbonate content $\left[\delta^{13} \mathrm{C}\right.$ and $\delta^{15} \mathrm{~N}$ values of approximately $-20 \%$ o to $-23 \%$ o and $\sim 6 \%$ o- $8 \%$, respectively]), corroborating previous studies in the area. Cyclic variation of these geochemical proxies corresponds strongly to glacial-interglacial cycles (Tada et al., 1999; Hyun et al., 2007). Migration of the Yellow and Yangtze Rivers toward the Japan Sea/East Sea and the exposure of the continental shelf during glacial periods likely caused an increase in terrestrial input, leading to depleted $\delta^{13} \mathrm{C}$ and $\delta^{15} \mathrm{~N}$ (Khim et al., 2007).

Site U1429 (Fig. F4) does not share geochemical trends similar to the other two sites because it is located outside of the Japan Sea/East Sea and is not isolated during glacioeustatic sea level changes. Site U1429 in the East China Sea is also unique in that it lacks the dark-light sediment alternations found at other Expedition 346 sites, likely caused by limited variation in nutrient supply and resulting paleoproductivity levels as well as oxic bottom water conditions.

Glacial periods reduce the inflow of the TWC into the restricted marginal sea, which in turn freshens the surface water and increases stratification in the water body while decreasing productivity (Khim et al., 2007; Xing et al., 2011). Therefore, during interglacial and interstadial periods, the influx of the TWC brings warmer, more nutrient-rich water that increases productivity in the water column. The increased productivity is inferred by increased \%Ca$\mathrm{CO}_{3}, \%$ TOC, and $\% \mathrm{~N}$ and enriched $\delta^{13} \mathrm{C}$ and $\delta^{15} \mathrm{~N}$ values during the interglacial periods.

\section{Acknowledgments}

We would like to thank Co-Chief Scientists Ryuji Tada and Richard W. Murray and all fellow participants of Expedition 346. This research used samples provided by the Integrated Ocean Drilling Program (IODP). Shore-based sample processing was funded through U.S. Science Support Program (USSSP) award 3499. John Harris and Maria Sabando aided with sample preparation and analysis. Samantha C. Bova provided beneficial comments that helped improve and clarify this manuscript. This is contribution number 862 from the Southeast Environmental Research Center in the Institute of Water and Environment at Florida International University.

\section{References}

Altabet, M.A., Murray, D.W., and Prell, W.L., 1999. Climatically linked oscillations in Arabian Sea denitrification over the past $1 \mathrm{~m} . \mathrm{y}$.: implications for the marine $\mathrm{N}$ cycle. Paleoceanography, 14(6):732-743. https://doi.org/10.1029/1999PA900035

Canuel, E.A., and Martens, C.S., 1996. Reactivity of recently deposited organic matter: degradation of lipid compounds near the sediment-water interface. Geochimica et Cosmochimica Acta, 60(10):1793-1806. https://doi.org/10.1016/0016-7037(96)00045-2

Cline, J.D., and Kaplan, I.R., 1975. Isotopic fractionation of dissolved nitrate during denitrification in the eastern tropical North Pacific Ocean. Marine Chemistry, 3(4):271-299. https://doi.org/10.1016/0304-4203(75)90009-2

Coplen, T.B., 2011. Guidelines and recommended terms for expression of stable-isotope-ratio and gas-ratio measurement results. Rapid Communications in Mass Spectrometry, 25(17):2538-2560.

https://doi.org/10.1002/rcm.5129 
Fry, B., and Sherr, E.B., 1984. $\delta^{13} \mathrm{C}$ measurements as indicators of carbon flow in marine and freshwater ecosystems. Contributions in Marine Science, 27:13-47.

Hyun, S., Bahk, J.J., Suk, B.-C., and Park, B.-K., 2007. Alternative modes of Quaternary pelagic biosiliceous and carbonate sedimentation: a perspective from the East Sea (Japan Sea). Palaeogeography, Palaeoclimatology, Palaeoecology, 247(1-2):88-99. https://doi.org/10.1016/j.palaeo.2006.11.023

Khim, B.K., Bahk, J.J., Hyun, S., and Lee, G.H., 2007. Late Pleistocene dark laminated mud layers from the Korea Plateau, western East Sea/Japan Sea, and their paleoceanographic implications. Palaeogeography, Palaeoclimatology, Palaeoecology, 247(1-2):74-87. https://doi.org/10.1016/j.palaeo.2006.11.029

Khim, B.K., Ikehara, K., Bahk, J.J., and Irino, T., 2008. Increased negative anomalies of sedimentary organic matter $\delta^{13} \mathrm{C}$ and $\delta^{15} \mathrm{~N}$ values in the East Sea (Sea of Japan) during the full glaciation of the late Quaternary. Quaternary International, 176-177:25-35. https://doi.org/10.1016/j.quaint.2007.05.016

Kitamura, A., Takano, O., Takata, H., and Omote, H., 2001. Late Pliocene-early Pleistocene paleoceanographic evolution of the Sea of Japan. Palaeogeography, Palaeoclimatology, Palaeoecology, 172(1-2):81-98. https://doi.org/10.1016/S0031-0182(01)00272-3

Lehmann, M.F., Bernasconi, S.M., Barbieri, A., and McKenzie, J.A., 2002. Preservation of organic matter and alteration of its carbon and nitrogen isotope composition during simulated and in situ early sedimentary diagenesis. Geochimica et Cosmochimica Acta, 66(20):35733584 . https://doi.org/10.1016/S0016-7037(02)00968-7

Mahaffey, C., Williams, R.G., Wolff, G.A., Mahowald, N., Anderson, W., and Woodward, M., 2003. Biogeochemical signatures of nitrogen fixation in the eastern North Atlantic. Geophysical Research Letters, 30(6):1300. https://doi.org/10.1029/2002GL016542

Mariotti, A., Germon, J.C., Leclerc, A., Catroux, G., and Letolle, R., 1981. Experimental determination of kinetic isotope fractionation of nitrogen isotopes during denitrification. In Schmidt, K., Forstel, H.L., and Heinzinger, H. (Eds.), Stable Isotopes: Proceedings of the 4th International Conference: New York (Elsevier Science).

Meyers, P.A., and Eadie, B.J., 1993. Sources, degradation and recycling of organic matter associated with sinking particles in Lake Michigan. Organic Geochemistry, 20(1):47-56. https://doi.org/10.1016/0146-6380(93)90080-U

Montoya, J.P., Korrigan, S.G., and McCarthy, J.J., 1991. Rapid, storm-induced changes in the natural abundance of ${ }^{15} \mathrm{~N}$ in a planktonic ecosystem, Chesapeake Bay, USA. Geochimica et Cosmochimica Acta, 553(12):3627-3638. https://doi.org/10.1016/0016-7037(91)90060-I
Oba, T., Kato, M., Kitazato, H., Koizumi, I., Omura, A., Sakai, T., and Takayama, T., 1991. Paleoenvironmental changes in the Japan Sea during the last 85,000 years. Paleoceanography, 6(4):499-518. https://doi.org/10.1029/91PA00560

O'Leary, M.H., 1981. Carbon isotope fractionation in plants. Phytochemistry, 20(4):553-567. https://doi.org/10.1016/0031-9422(81)85134-5

Peterson, B.J., and Howarth, R.W., 1987. Sulfur, carbon, and nitrogen isotopes used to trace organic matter flow in the salt-marsh estuaries of Sapelo Island, Georgia. Limnology and Oceanography, 32(6):1195-1213. https://doi.org/10.4319/lo.1987.32.6.1195

Tada, R., Irino, T., and Koizumi, I., 1999. Land-ocean linkages over orbital and millennial timescales recorded in late Quaternary sediments of the Japan Sea. Paleoceanography, 14(2):236-247. https://doi.org/10.1029/1998PA900016

Tada, R., Koizumi, I., Cramp, A., and Rahman, A., 1992. Correlation of dark and light layers, and the origin of their cyclicity in the Quaternary sediments from the Japan Sea. In Pisciotto, K.A., Ingle, J.C., Jr., von Breymann, M.T., Barron, J., et al., Proceedings of the Ocean Drilling Program, Scientific Results, 127/128 (Part 1): College Station, TX (Ocean Drilling Program), 577-601. https://doi.org/10.2973/odp.proc.sr.1271281.160.1992

Tada, R., Murray, R.W., Alvarez Zarikian, C.A., Anderson, W.T., Jr., Bassetti, M.-A., Brace, B.J., Clemens, S.C., da Costa Gurgel, M.H., Dickens, G.R., Dunlea, A.G., Gallagher, S.J., Giosan, L., Henderson, A.C.G., Holbourn, A.E., Ikehara, K., Irino, T., Itaki, T., Karasuda, A., Kinsley, C.W., Kubota, Y., Lee, G.S., Lee, K.E., Lofi, J., Lopes, C.I.C.D., Peterson, L.C., Saavedra-Pellitero, M., Sagawa, T., Singh, R.K., Sugisaki, S., Toucanne, S., Wan, S., Xuan, C., Zheng, H., and Ziegler, M., 2015a. Expedition 346 summary. In Tada, R., Murray, R.W., Alvarez Zarikian, C.A., and the Expedition 346 Scientists, Proceedings of the Integrated Ocean Drilling Program, 346: College Station, TX (Integrated Ocean Drilling Program). https://doi.org/10.2204/iodp.proc.346.101.2015

Tada, R., Murray, R.W., Alvarez Zarikian, C.A., Anderson, W.T., Jr., Bassetti, M.-A., Brace, B.J., Clemens, S.C., da Costa Gurgel, M.H., Dickens, G.R., Dunlea, A.G., Gallagher, S.J., Giosan, L., Henderson, A.C.G., Holbourn, A.E., Ikehara, K., Irino, T., Itaki, T., Karasuda, A., Kinsley, C.W., Kubota, Y., Lee, G.S., Lee, K.E., Lofi, J., Lopes, C.I.C.D., Peterson, L.C., Saavedra-Pellitero, M., Sagawa, T., Singh, R.K., Sugisaki, S., Toucanne, S., Wan, S., Xuan, C., Zheng, H., and Ziegler, M., 2015b. Methods. In Tada, R., Murray, R.W., Alvarez Zarikian, C.A., and the Expedition 346 Scientists, Proceedings of the Integrated Ocean Drilling Program, 346: College Station, TX (Integrated Ocean Drilling Program). https://doi.org/10.2204/iodp.proc.346.102.2015 
Watanabe, S., Tada, R., Ikehara, K., Fujine, K., and Kido, Y., 2007. Sediment fabrics, oxygenation history, and circulation modes of Japan Sea during the Late Quaternary. Palaeogeography, Palaeoclimatology, Palaeoecology, 247(12):50-64.

https://doi.org/10.1016/j.palaeo.2006.11.021

Xing, L., Zhang, R., Liu, Y., Zhao, X., Liu, S., Shi, X., and Zhao, M., 2011. Biomarker records of phytoplankton productivity and community structure changes in the
Japan Sea over the last 166 kyr. Quaternary Science Reviews, 30(19-20), 2666-2675.

https://doi.org/10.1016/j.quascirev.2011.05.021

Initial receipt: 30 June 2017

Acceptance: 7 February 2018

Publication: 25 May 2018

MS 346-204 
Figure F1. Locations of all nine Expedition 346 drilling sites in Japan Sea/East Sea and East China Sea (modified from the "Expedition 346 summary" chapter [Tada et al., 2015a]). Blue dots = sites used in this study.

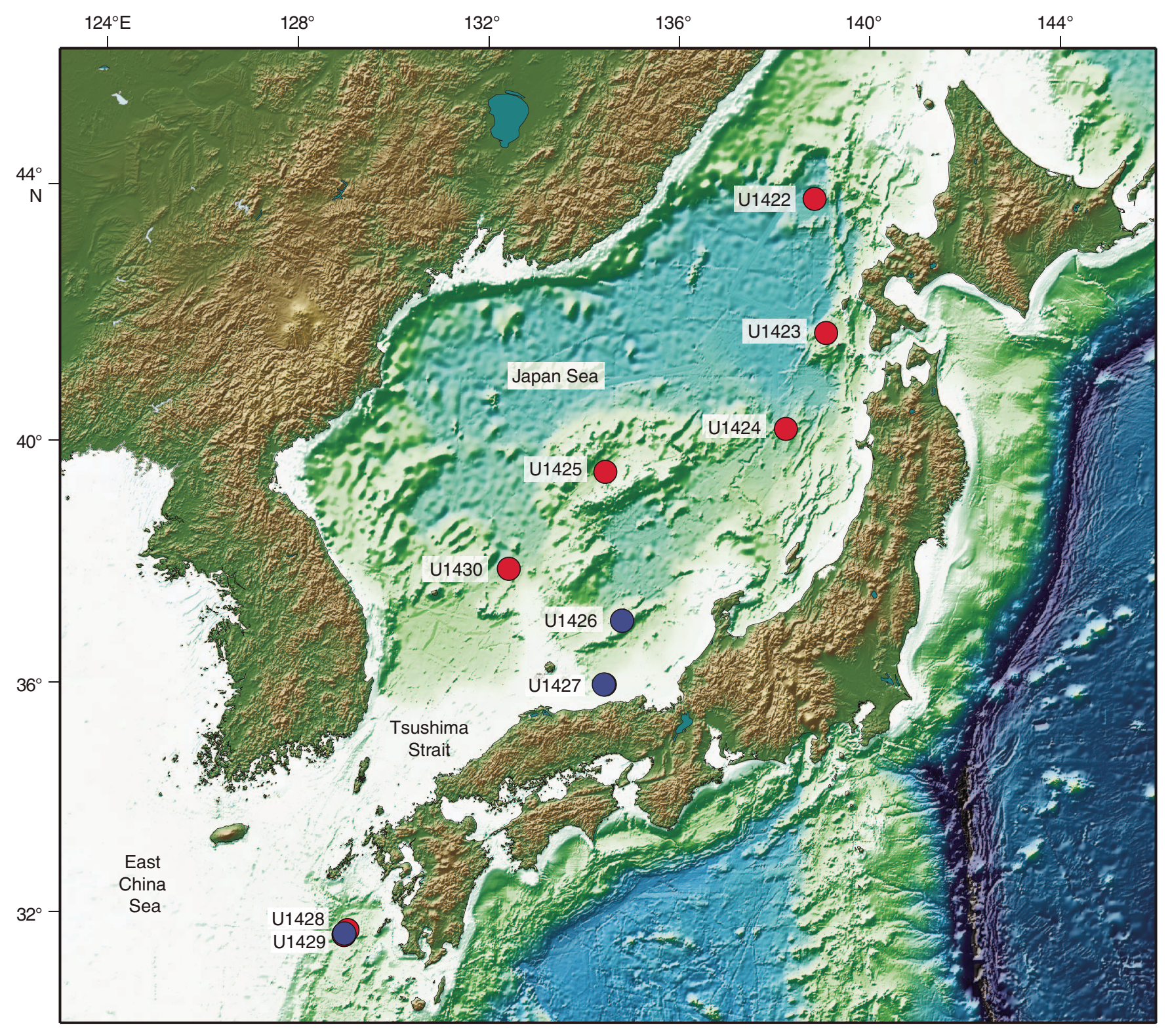


Figure F2. Calcium carbonate $\left(\% \mathrm{CaCO}_{3}\right)$, total organic carbon $(\% \mathrm{TOC})$, total nitrogen $(\% \mathrm{~N}), \delta^{13} \mathrm{C}$, and $\delta^{15} \mathrm{~N}$ content of sediment samples and $b^{*}$ data, Site U1426. Shaded regions represent glacial periods.

U1426

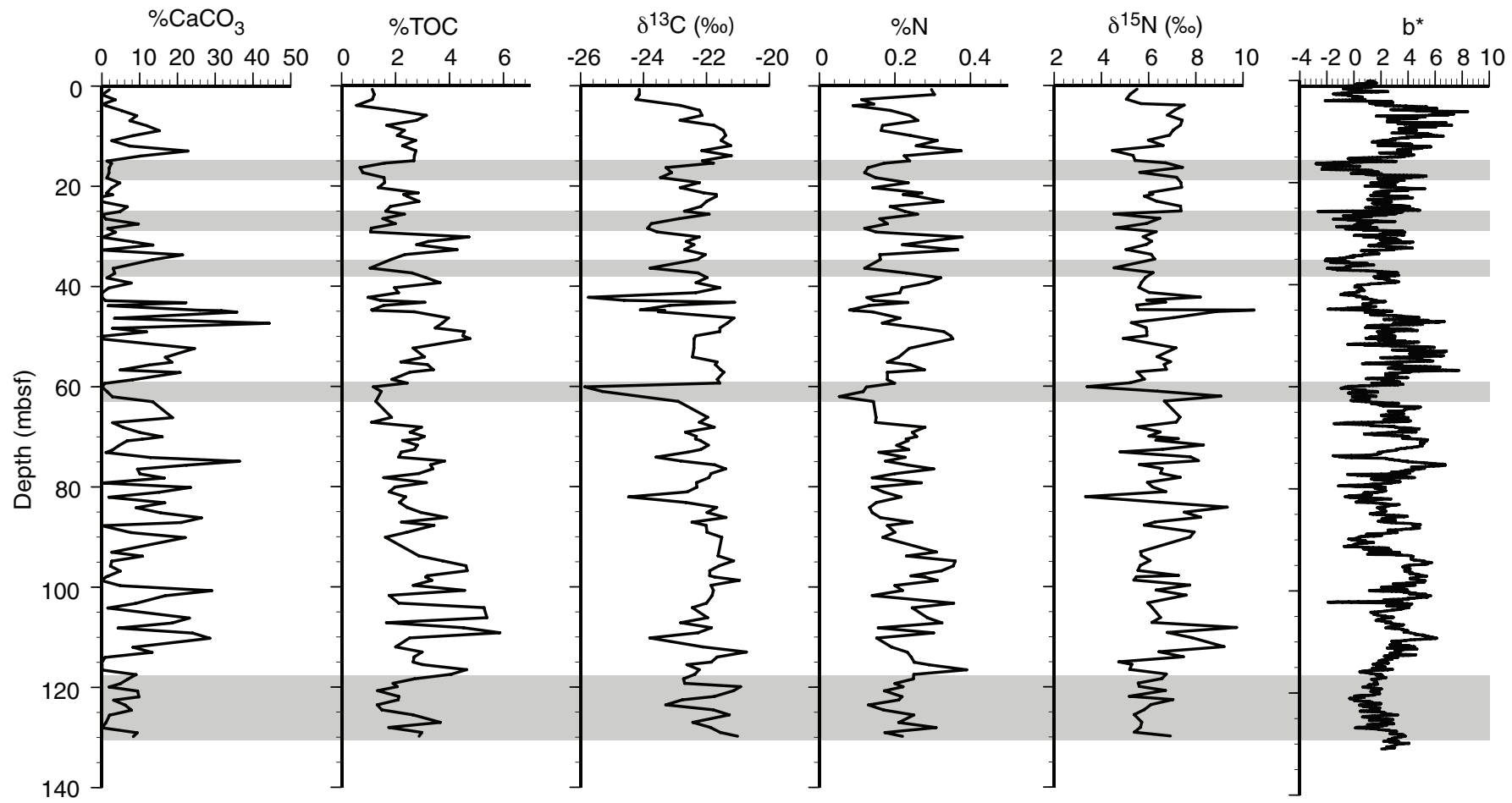

Figure F3. Calcium carbonate $\left(\% \mathrm{CaCO}_{3}\right)$, total organic carbon $(\% \mathrm{TOC})$, total nitrogen $(\% \mathrm{~N}), \delta^{13} \mathrm{C}$, and $\delta^{15} \mathrm{~N}$ content of sediment samples and $\mathrm{b}^{*}$ data, Site U1427. Shaded regions represent glacial periods.

U1427

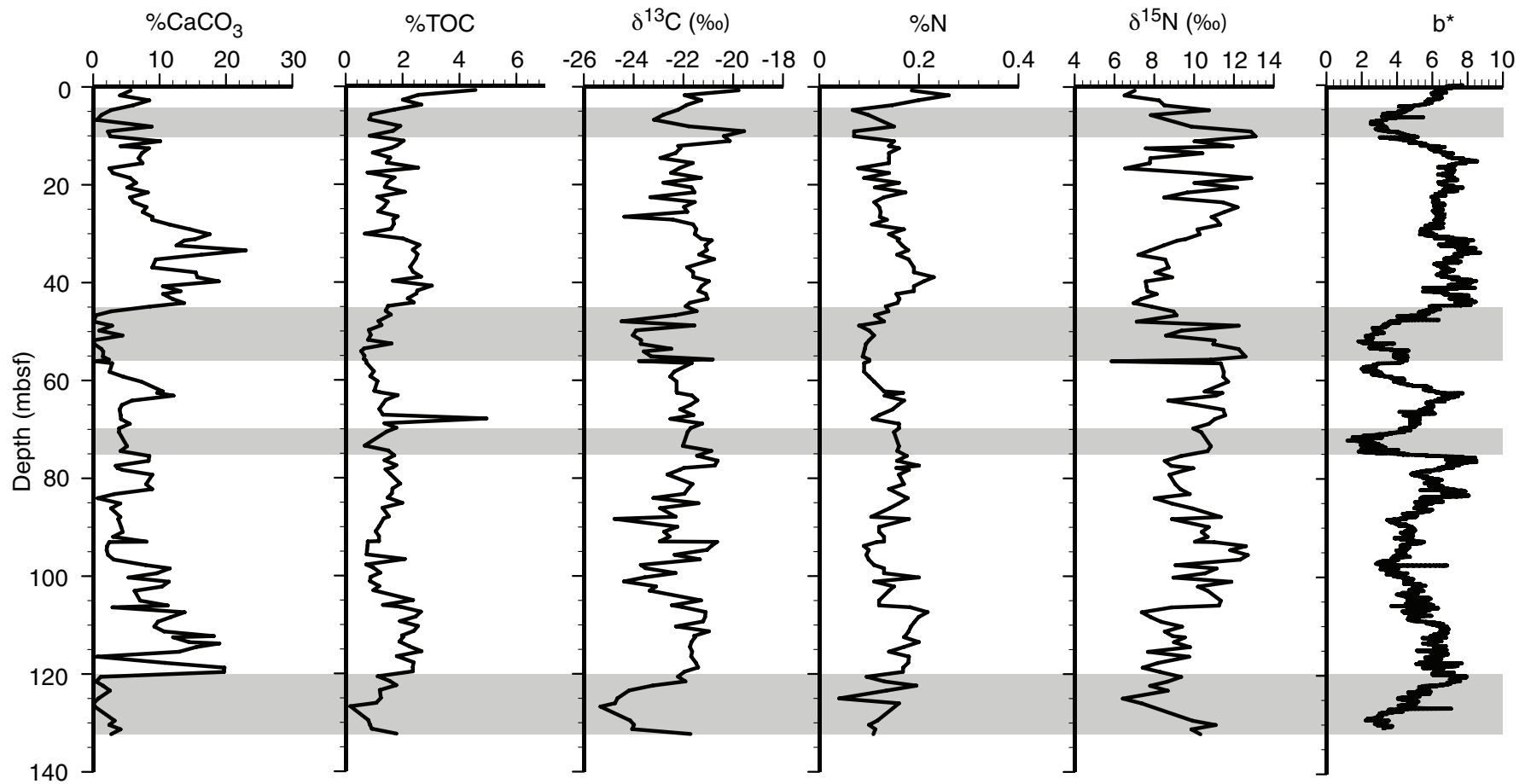


Figure F4. Calcium carbonate $\left(\% \mathrm{CaCO}_{3}\right)$, total organic carbon $(\% \mathrm{TOC})$, total nitrogen $(\% \mathrm{~N}), \delta^{13} \mathrm{C}$, and $\delta^{15} \mathrm{~N}$ content of sediment samples and $b^{*}$ data, Site U1429.

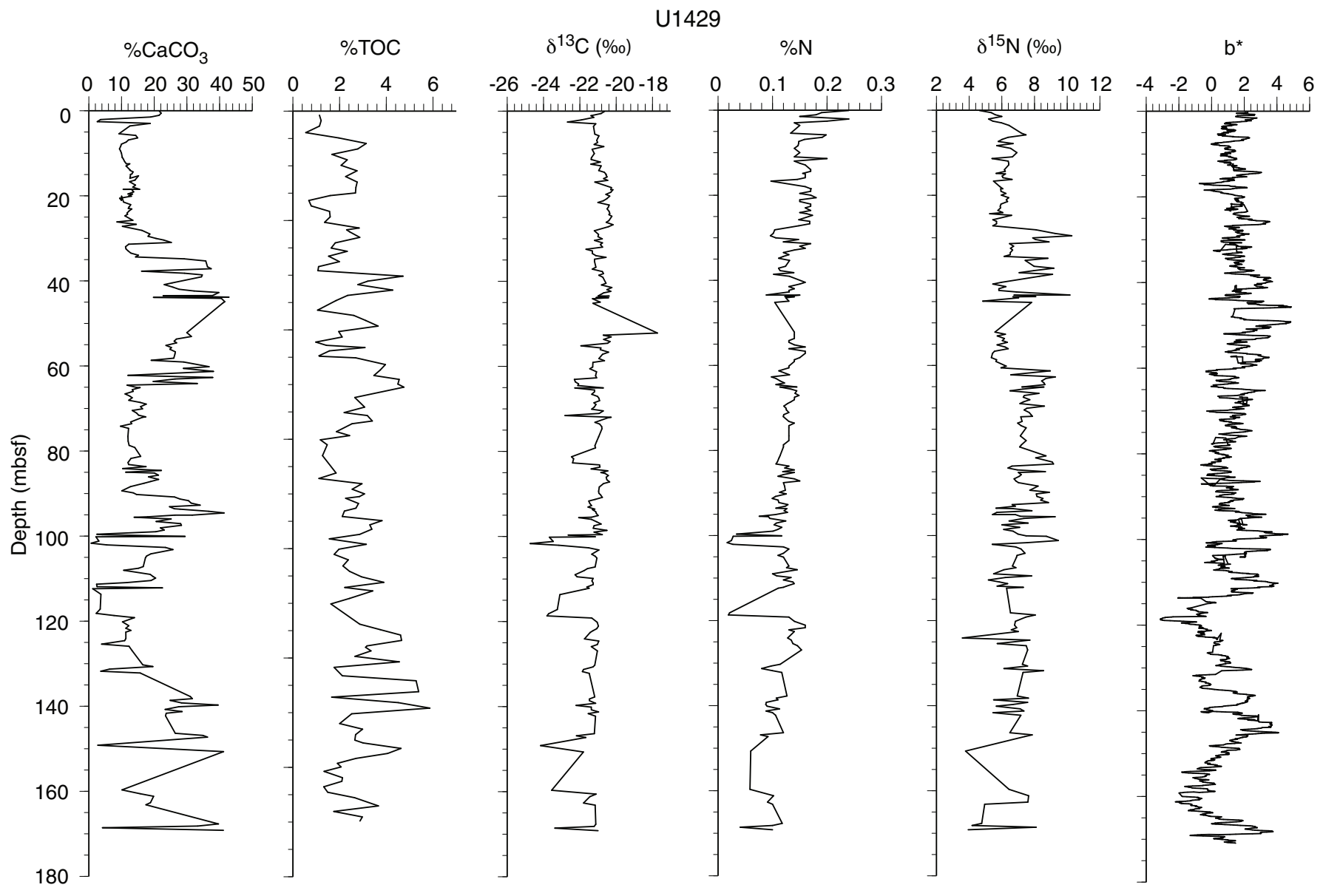


Table T1. $\% \mathrm{CaCO}_{3}, \% \mathrm{TOC}, \% \mathrm{~N}, \delta^{13} \mathrm{C}$, and $\delta^{15} \mathrm{~N}$ content of sediment samples, Site U1426. This table is available in CSV format.

Table T2. $\% \mathrm{CaCO}_{3}, \% \mathrm{TOC}, \% \mathrm{~N}, \delta^{13} \mathrm{C}$, and $\delta^{15} \mathrm{~N}$ content of sediment samples, Site U1427. This table is available in CSV format.

Table T3. $\% \mathrm{CaCO}_{3}, \% \mathrm{TOC}, \% \mathrm{~N}, \delta^{13} \mathrm{C}$, and $\delta^{15} \mathrm{~N}$ content of sediment samples, Site U1429. This table is available in CSV format. 